\title{
Stock Market Liberalization, Stock Market Performance and Economic Growth in Kenya
}

\author{
Isaac Kimunio Kinuthia ${ }^{1} \&$ Martin N. Etyang $^{1}$ \\ ${ }^{1}$ School of Economics, Kenyatta University, Nairobi, Kenya \\ Correspondence: Isaac Kimunio Kinuthia, School of Economics, Kenyatta University, P. O. Box 26588-00100, \\ Nairobi, Kenya. Tel: 254-72-416-0815. E-mail: kinuthiaisaac@gmail.com
}

Received: January 15, 2014

Accepted: February 2, 2014

Online Published: March 25, 2014

doi:10.5539/ijef.v6n4p196

URL: http://dx.doi.org/10.5539/ijef.v6n4p196

\begin{abstract}
The study empirically examined whether stock market liberalization improves the functioning of domestic stock market and accelerates economic growth in Kenya. The study also assessed the kind of relationship between liberalization, stock market performance and economic growth in Kenya. Liberalization was assessed by stock market capitalization while turnover was used to asses stock market performance. The study used quarterly time series data collected through secondary sources and covered a period of 22 years from January, 1991 to December, 2012. The study utilized econometric techniques of Vector autoregressive and Granger Causality Tests to investigate the relationships. The results displayed a one way causality that runs from stock market development to economic growth. The results also show that stock market liberalization indirectly impacts on economic growth through investment. The study found that stock market liberalization has a significant positive impact on the economic growth in Kenya.
\end{abstract}

Keywords: liberalization, market capitalization, turnover, economic growth

\section{Introducation}

Stock market liberalization can be defined as a decision by a country's government to allow foreigners to purchase shares in that country's stock market. The theory of the standard international asset pricing model (IAPM) predicts that stock market liberalization may reduce the liberalizing country's cost of equity capital. There are two important empirical implications for stock market liberalization (Henry, 2000). First, stock market liberalization tends to boost the stock market liquidity. The second implication is that there is an increase in physical investment following stock market liberalization, due to a fall in a country's cost of equity which spurs real private investment. Research has shown that on average, countries experience large, temporary increases in the growth rate of real private investment following stock market liberalization (Henry, 2000). If other factors are held constant, such as political and economic reforms, oil prices among others, the relationship between private investment growth and stock market liberalization is observed.

Akingunola et al. (2013), opines that, the financial sector of any economy in the world plays a vital role in the development and growth of the economy. The development of this sector determines how it will be able to effectively and efficiently discharge its major role of mobilizing fund from the surplus sector to the deficit sector of the economy (Akingunola et al., 2013). If a financial system is well-developed, it will enhance investment by identifying and funding good business opportunities, mobilize savings, enable the trading, hedging and diversification of risk and facilitate the exchange of goods and services (Akingunola et al., 2013). Liberalization can result in a more efficient stock market, which can in turn result in economic growth.

The impact of foreign investors on the performance of the stock market is, however, not clear. There is a controversy concerning the role of financial opening in the development and growth of the economy. It is for example observed that greater foreign participation in the market may cause stock volatility. Sellin (1996), regards foreign investors' participation as noise trading, therefore a source of excess volatility in the market. Krugman (1993) also argues that financial integration is unlikely to spur economic development.

Table 1 shows the trend of improved development of the stock market including the openness (market capitalization) and performance (shares turnover) after stock market liberalization in 1995. 
Table 1. Nse gross market statistics, 1990-2011

\begin{tabular}{llllllllll}
\hline Year & 1990 & 1994 & 1995 & 1996 & 2000 & 2005 & 2010 & 2011 & 2012 \\
\hline Market Capitalization. (KShs. Bn) & 10.9 & $1,286.6$ & $1,230.5$ & $1,190.2$ & $1,306.0$ & 36.6 & 110.3 & 78.1 & $12,822.8$ \\
Shares Turnover (KShs. Bn) & 0.2 & 3.1 & 3.3 & 3.9 & 3.6 & $4,826.9$ & $13,070.3$ & $12,429.6$ & 86.7 \\
\hline
\end{tabular}

Source: NSE.

Turnover increased from a low of less than Kshs. 1 billion in 1990 to more than Kshs. 3 billion in 1995 reaching a high of Kshs. 110.3 billion in 2010. The same trend was witnessed in market capitalization, with the highest level of Kshs. 13,070 billion being recorded in 2010 from 10.9 billion in 1990.

Figure 1 shows the economic performance in Kenya in terms of GDP growth and stock market performance as percentage of GDP from 1990 to 2012. Stock market performance is measured in terms of turnover ratio, total value of stocks traded and Market capitalization of listed companies.

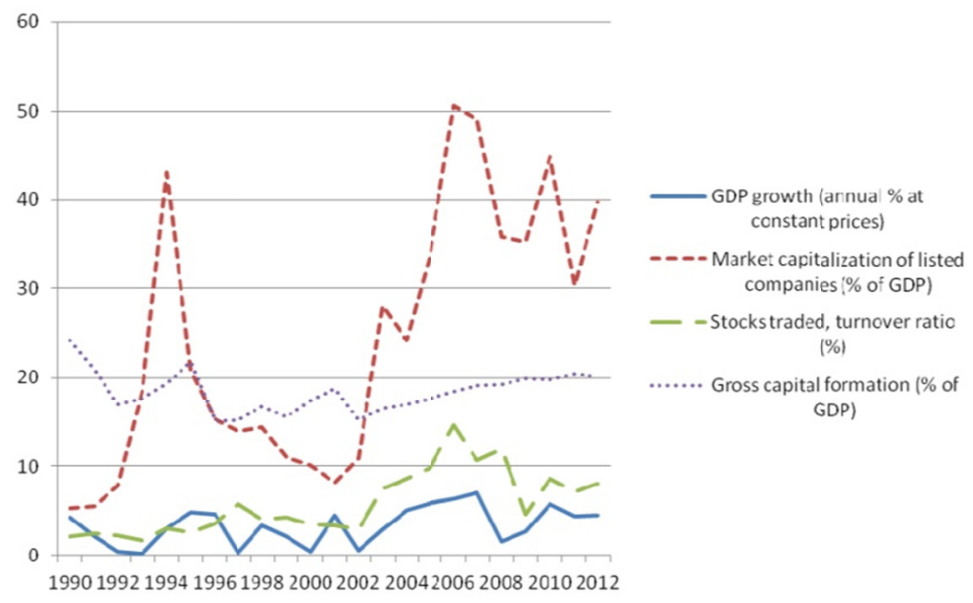

Figure 1. Economic and stock market performance in Kenya for the period 1990-2012

Source: Computations using data from NSE, KNBS and World Bank.

The stock market shows significant improvements in all indicators with market capitalization (\% of GDP) rising from a low of 5.28\% in 1990 to a high of 49.2\% in 2006. Turnover ratio (\%) rose from 2.10 in 1990 to 5.78 in 1997 and 14.63 in 2006.

In the1970s, the government saw a need to directly monitor the operations of the stock market in an effort to ensure that capital raised in the market was not used for investment outside the country (Republic of Kenya, 1969). Tight taxation policies were implemented to reduce repatriation of funds by foreigners and to raise government revenue. The government made a first attempt to regulate the stock market with the establishment of the Capital Issue Committee (CIC) in 1971 with responsibility of controlling capital outflow (Ngugi, 2003a). The idea came due to an observed practice by foreign investors that after selling shares to local investors, they were following up with the request to remit the funds realized overseas. The government wanted to discourage such a move.

During the revitalization period, capital controls were relaxed for offshore borrowing in February 1994 and a complete liberalization of offshore borrowing was implemented in May, 1994. Some restrictions on inward portfolio investment were lifted in January 1995, therefore, allowing participation of foreign investors in the Nairobi Stock Exchange trading under guided policy. Foreign investors were permitted up to $20 \%$ of equity for inward portfolio investment that is aggregate of each stock and a $2.5 \%$ limit for individual investors (Ngugi, 2003a). In 1995, foreign investors' participation in the stock market was increased to $5 \%$ for an individual investor and $40 \%$ aggregate in any locally controlled company so as to encourage foreign portfolio investment (CMA annual report, 1999). The whole exchange control act was revoked in December, 1995 (Ngugi, 2003a). Henry (2000) identifies the time of a country's initial stock market liberalization with a demonstrable happening of any of the following: liberalization by policy decree, creation of the first country fund, or an increase in the investability index of at least $10 \%$ (Henry, 2000). Thus, it can be noted that the official liberalization date for NSE was January 1995. The subsequent policies were measures to further encourage foreign portfolio flows through the NSE. 
Figure 2 shows the trend of foreign portfolio investment at the NSE.

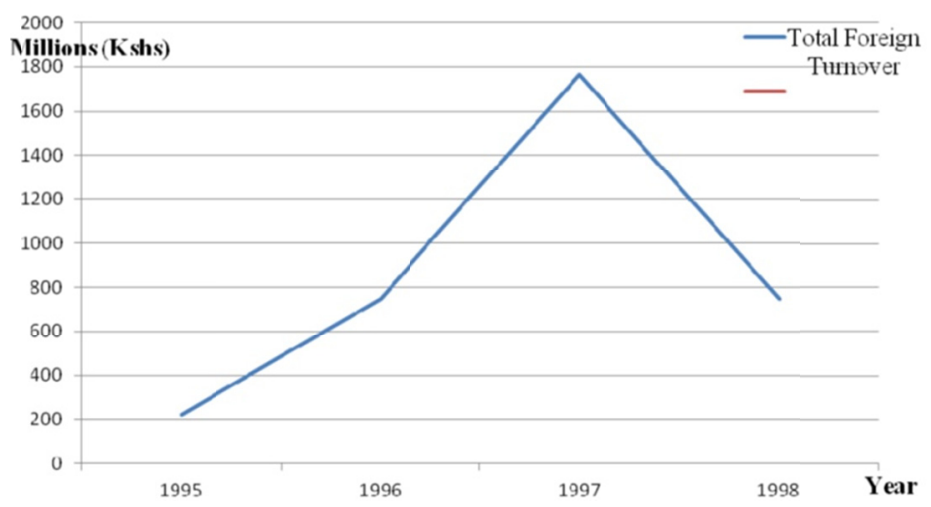

Figure 2. NSE total foreign turnover (Kshs millions)

Source: Computations using data from NSE.

Initially, when foreign investors were allowed to trade in January, 1995, a slow growth in foreign trading was recorded. Inflow of foreign trade increased tremendously with the increased limit of foreign participation in July 1995. There was tremendous growth in foreign investors' activities, increasing from 3\% in 1995 to $44 \%$ in June 1997, with a peak in December 1996 of $52.5 \%$. This growth can lead to a conclusion that market performance during the 1996-1997 periods was to a large extent controlled by foreign operations (Ngugi, 2003a).

The capital market in Kenya is still small in size with limited listings, relatively low liquidity and is faced with significant structural and regulatory weaknesses (Nyang'oro, 2012). The NSE suffers from a lack of liquidity and the market is somewhat speculative. Political uncertainties in the country do affect the performance of NSE. For example, the period before the 2002 general election saw a reduction in share trading and a fall in market prices. Insider trading is a common feature of many stock markets and the NSE is not different. Although there are laws to prevent insider trading, enforcements are not always effective and investors get worse prices and rates of return.

\subsection{Statement of the Problem}

Like many other developing countries one of the most fundamental objectives of Kenya's macroeconomic policies is to sustain high economic growth in an attempt to move from a developing to a developed economy. One of the key pillars to achieving this is attracting local and foreign investment in the key strategic sectors of our economy. To achieve this, the Government must look at ways that attract foreign investment in our country. One way of attracting foreign investment is through the liberalization of the Nairobi Securities Exchange. Since the financial system performs the vital role of raising funds and channeling them to productive investment, effective financial liberalization is therefore an important element of a country's policy for economic growth (Akingunola et al., 2013). Despite the efforts made to promote growth of the capital market and the financial sector in general, the contribution of the sector to economic development was viewed as unsatisfactory as the economy hanged on the balance with dwindling inflows of foreign savings and low stock market performance. Consequently, the government viewed the reform of the sector as the best option especially if the economy was to shift its reliance on domestic resources to finance domestic investment (Republic of Kenya, 1974). Nyang'oro (2012) opines that Kenya still has low levels of portfolio inflows but this has been growing over time. Hence, it is important to consider the likely effect of such flows on the economy. The Exchange was opened to foreign investors for the first time in January 1995. Given that the stock market is liberalized, it is necessary to be cognisant of the implications of this on the economic growth. It is against this background that this study intended to empirically examine the impact of stock market liberalization on the performance of Nairobi Securities Exchange and economic growth rate in Kenya. The study further sought to find out if economic growth influences performance of the stock market or if it is the stock market that affects economic growth.

\subsection{Objectives of the Study}

The broad objective of this study was to consider the effect of liberalization of Nairobi Securities Exchange on economic growth in Kenya. The study set out to demonstrate whether there was a structural change in economic growth that took place in 1995 as a result of liberalization. The study also sought to determine direction of causality between stock market liberalization, stock market performance and economic growth in Kenya. 


\subsection{Literature Review}

Several studies reveal that liberalization encompasses a positive impact to the economy. Liberalization increases stock market liquidity which in turn leads to a large underlying impact on economic growth by affecting total factor productivity growth. The review focused on studies that were conducted to evaluate the effects of stock market liberalization on stock market performance or economic growth.

McKinnon (1973) and Shaw (1973) in their separate studies put forward the financial liberalization thesis contending that a government restriction on the financial system has pinned down the quantity and quality of investment. They postulate that the poor performance of investment and growth in developing countries is a function of interest rate ceiling, high reserve requirement and restrictions in credit allocation mechanism. These elements were the sources of financial repression, the main symptoms of which include low savings, credit rationing and low investment. They also postulate that removing financial restrictions in any economy can influence a positive effect on growth rates as interest rates rise toward competitive market equilibrium.

There is a growing body of literature stressing a direct relationship between the extents to which financial liberalization can improve performance and the various measures of efficiency. Liberalization is most likely accompanied by an increase in the amount of research done on individual stock and market conditions in the equity markets. This will lead to improved information availability to both foreign and domestic investors (Henry, 2000). It can also be noted that increased monitoring associated with opening a firm's stocks to foreign investors may improve the governance of the firm, which could force the firm's managers to improve on efficiency, profitability and other measures of operating performance (Henry \& Chari, 2002). Stock markets may also stimulate greater corporate control by making it easier to tie managerial compensation to performance (Diamond \& Verrecchia, 1982).

Stock markets may also influence risk diversification and avoid liquidity risk. Liquid equity markets make long-term investment more attractive because they allow savers to sell equities quickly and cheaply if they need access to their savings. Simultaneously, companies enjoy permanent access to capital raised through equity issues. By easing longer term, more profitable investments, liquid markets improve the allocation of capital and thereby enhance productivity growth (Levine, 1997).

Henry (2000) employs an event study method that assesses the growth rate of private investment during stock market liberalization periods with the growth rate of private investment during non- liberalization periods. The study comprised a sample of 11 developing countries that liberalized their stock markets. The study found that the mean growth rate of private investment in the three years immediately following stock market liberalization exceeds the sample mean by 22 per cent. This shows that there was a temporary increase in growth rate of private investment after liberalization.

Levine (2000) used data from 15 emerging economies to assess whether international financial liberalization, by improving the functioning of domestic financial markets and banks, accelerates economic growth. The study used Perron's (1989) test for structural breaks to evaluate whether stock market liquidity changes after the policy change date. The study found that liberalizing restrictions on international portfolio flows tends to enhance stock market liquidity. In turn, enhanced stock market liquidity accelerates economic growth mainly by improving productivity growth.

Fuchs-Schundeln and Funke (2001) analyzed the effects of stock market liberalization on financial and macroeconomic development using a cross-sectional data from twenty-seven countries. The study found an increase in real private investment growth by 6 percentage points in the second year after liberalization and cumulatively by about 14 percentage points in the four years following liberalization. The study also found a rise in real GDP per capita growth of about 1 per cent during the first four years after liberalization and a permanent growth effect of about 0.4 per cent per annum. The study concluded that growth tends to be greater where institutional reforms precede liberalization. The study also concluded that stock market and private investment happen to be two essential and interrelated avenues through which liberalization boosts real growth. It found that stock market liberalization stimulates stock market development which facilitates private investment, which in turn stimulates growth.

Ngugi (2003b) did a study on liquidity of NSE and found that although foreign investors boost trading activity; their significant contribution to liquidity is inhibited by their noise trading behaviour and regulatory system that short-lived institutional investors thrive on for trading activity. The study found that increasing the pull factors for foreign investors in the market is important in order to experience gains in trading activities. This could be coupled with creation of a favourable macroeconomic environment for investment. The study invoked the microstructure theory for empirical analysis testing for market response of trading activity and liquidity of the NSE to the 
implemented institutional and policy reforms during the revitalization process.

Tswamuno, Pardee and Wunnava (2007) in their study on financial liberalization and economic growth asserted that liberalization of the equity and bond markets in South Africa did not intensify economic growth. The study opined that even though liberalization absolutely led to a strong upsurge in capital flowing into South Africa, investor speculation, instigated by an unhealthy macro-economic environment and political uncertainty led to huge fluctuations of capital flows and subsequent capital flight. The study demonstrates that liberalization of the capital account is an essential, but not adequate necessity for economic development.

In summary, the above literature shows the beneficial effects of liberalization to stock market liquidity and economic growth. It is also clear from the various studies cited above that liberalization is most effective in emerging economies. Emphasis was placed on literature that covered stock market liberalization. Even though there are many studies on stock market liberalization, this study differs from other studies in some dimensions. First, the data used were from 1991 to 2012 so as to enable the study to examine both pre and post-liberalization periods. Second, the study used a detailed country level analysis since it was focusing on impact of stock market liberalization in Kenya only. Henry (2000), Levine (2000) and Fuchs-Schundeln and Funke (2001) examined the effects of financial liberalization in a cross-country setting and Kenya was not among the countries under their study. There is a possibility of differing results in the case of Kenya. Third, the study closed the knowledge gaps by looking into impact of stock market liberalization on stock market performance and economic growth in Kenya. The study by Ngugi (2003b) was not specifically analyzing the impact of stock market liberalization.

\section{Research Methodology}

\subsection{Introduction}

The broad objective of this study was to measure the impact of stock market liberalization on economic growth in Kenya. This chapter discusses the data and empirical model used to measure this objective. To ascertain whether stock market liberalization produces positive effects, it is necessary to ultimately observe its effect on economic growth (Fuchs-Schundeln \& Funke, 2001). To better apprehend the processes behind the liberalization effects, two possible channels through which liberalization can nurture stock market development are focused, namely; its impact on stock market capitalization and its subsequent impact on stock market liquidity. Stock market liberalization will increase market capitalization through foreign portfolio investments.

\subsection{Research Design}

A research design includes the methodology and process employed to conduct a research. The choice of a research design is critical as far as every research is concerned. For the purpose of this study, non-experimental design was used. The reason is because data are already in existence and the study was intended to examine the impact of one variable on the other variable.

\subsection{Model Specification}

The principal variables in the analysis were measures of economic growth and stock market development. Gross domestic product (GDP) per capita was used as a measure of the level of economic growth while market capitalization (\% of GDP) was used as a proxy for liberalization and turnover ratio (TOR) was used to reflect the level of stock market performance. The control variable used to avoid possible omitted variable bias is Gross fixed capital formation (\% of GDP) as a proxy of investment (INV). Thus, the framework contains four variables-GDP per capita growth rate, turnover ratio, market capitalization and investment. The study used a vector autoregressive (VAR) structure to examine the relationship between the variables. This was done once stationarity tests had been carried out using the Augmented Dickey Fuller unit root.

Denote $X=$ (GDP, TOR, MC, INV), the following VAR model is used in the analysis;

$$
X_{t}=\alpha i+\sum_{t=1}^{n} \beta i X_{t-1}+u_{t}
$$

Where;

$X_{t}=\left[\begin{array}{c}\mathrm{GDP} \\ \mathrm{TOR} \\ \mathrm{MC} \\ \mathrm{INV}\end{array}\right]$;

which is a vector of variables and $\beta_{i}$ are vector of coefficients, $\alpha_{i}$ is a vector of constant terms while $u_{t}$ is a vector of error terms. 
Since the variables were not integrated of the same order, an unrestricted VAR model was estimated instead of a Vector Error Correction Model.

\subsection{Definition and Measurement of Variable}

The study used GDP per capita growth rate as a measure of the level of economic growth since it focuses on real domestic production per. GDP per capita is the favored measure of economic growth by Ibrahim, 2011 and Zivengwa et al. (2011).

Turnover ratio (TOR) was used as proxy for stock market performance. The TOR is a common indicator for stock market activities within the financial system (Levine \& Zervos, 1998). Stock market liquidity is the extent to which an asset or security can be bought or sold without causing a major movement in the price and with minimum loss of value. Liquidity is indicated by a high level of trading activity. To measure stock market liquidity, the study used the turnover Ratio, which equals the value of stock transactions divided by market capitalization.

$$
\text { Liquidity }=\frac{\text { Total Value Traded }}{\text { Market Capitalization }}
$$

Stock market liquidity is expected to have a positive link with economic growth (Levine \& Zervos, 1998).

Market capitalization (MC), was used as a proxy for stock market liberalization. Stock market liberalization increases market capitalization or size of the stock market through foreign portfolio investment. Market capitalization refers to the product of outstanding shares and market price of equities on a stock exchange. This portrays the size of the stock market and is expected to be positively related with economic growth. Market capitalization as a percentage of GDP is preferred measure of stock market development as it is used to show the growth in terms of size of the stock exchange (Ibrahim, 2011; Zivengwa et al., 2011).

Gross fixed capital formation (\% of GDP) is used as a proxy for real investment (INV) in line with other studies such as Levine and Zervos (1998), Zivengwa et al. (2011) among others. Liberalization and efficiency of the stock market can boost investment which ultimately strengthens economic growth.

\subsection{Data Sources}

The study used secondary quarterly market level data from the period January, 1991 to December, 2012. The data was obtained from The NSE, Kenya National Bureau of Statistics (KNBS) and the World Bank databank.

\subsection{Data Analysis and Interpretation}

The variables were found to be integrated of different orders and an unrestricted VAR was used to make inferences on the impact of the stock market liberalization on economic growth. Impulse response functions and variance decomposition functions were analysed from the unrestricted VAR. The Engle-Granger test was used to give the causality relationship among variables.

\section{Results}

\subsection{Introduction}

The data are quarterly spanning the period 1991 quarter one to 2012 quarter four. Data on GDP per capita growth rate and Gross fixed capital formation were obtained from the Kenya National Bureau of Statistics and World Bank data base. The data for market capitalization and turnover ratio are from the Nairobi Securities Exchange. All the data were only available annually and thus a frequency conversion to quarterly was done using Eviews. The frequency conversion was done using the linear-match last method. This inserts the low observation value into the last period of the high frequency data, and then performs linear interpolation on the missing values.

\subsection{Empirical Findings}

\subsubsection{Stationarity Test}

Each time series variable is subjected to ADF test to test for stationarity as a preliminary analysis. Both drift and constant terms were included in the test equation and the AIC was used for the optimum lag order in the ADF test. Table 2 presents the results for unit root tests in levels. GDP and INV were stationary at the 5\% level of significance implying that they were integrated of order 0 that is $\mathrm{I}(0)$. 
Table 2. ADF unit root tests at levels

\begin{tabular}{llllll}
\hline Variable & ADF test Statistic & $1 \%$ critical Value & $5 \%$ critical Value & $10 \%$ critical Value & Result \\
\hline GDP & $-3.515998^{* *}$ & -4.080021 & -3.468459 & -3.161067 & Stationary \\
INV & $-3.587224 * *$ & -4.06829 & -3.462912 & -3.157836 & Stationary \\
MC & $-3.587224 * *$ & -4.080021 & -3.468459 & -3.161067 & Non Stationary \\
TOR & -2.740791 & -4.073859 & -3.465548 & -3.159372 & Non Stationary \\
\hline
\end{tabular}

Note. the test equations include both drift and trend terms. The lag order in the ADF test equation is based on AIC. *, ** and *** denotes significance at $1 \%, 5 \%$ and $10 \%$ respectively.

After first differencing (Table 3), the results showed that MC and TOR were still not stationary and further differencing was required.

Table 3. ADF unit root tests at first differences

\begin{tabular}{llllll}
\hline Variable & ADF test Statistic & $1 \%$ critical Value & $5 \%$ critical Value & $10 \%$ critical Value & Result \\
\hline MC & -2.411263 & -4.080021 & -3.468459 & -3.161067 & Non Stationary \\
TOR & -2.468203 & -4.073859 & -3.465548 & -3.159372 & Non Stationary \\
\hline
\end{tabular}

Note. the test equations include both drift and trend terms. The lag order in the ADF test equation is based on AIC. *, ** and *** denotes significance at $1 \%, 5 \%$ and $10 \%$ respectively.

After second differencing (Table 4), market capitalization and turnover ratio become stationary at the $1 \%$ level of significance. This shows that MC and TOR were integrated of order 2 that is I(2).

Table 4. ADF unit root tests at second differences

\begin{tabular}{llllll}
\hline Variable & ADF test Statistic & $1 \%$ critical Value & $5 \%$ critical Value & $10 \%$ critical Value & Result \\
\hline MC & $-5.135727 *$ & -4.080021 & -3.468459 & -3.161067 & Stationary \\
TOR & $-12.82632 *$ & -4.073859 & -3.465548 & -3.159372 & Stationary \\
\hline
\end{tabular}

Note. the test equations include both drift and trend terms. The lag order in the ADF test equation is based on AIC. *, ** and *** denotes significance at $1 \%, 5 \%$ and $10 \%$ respectively.

Since the variables were integrated of different orders, the study considered an unrestricted VAR model which was constructed using stationary variables. A suitable optimal lag length was found to be 4 using both the Schwarz information criterion (SC), the Akaike Information Criteria (AIC) and Hannan-Quinn information criterion (HQ). Table 5 presents the VAR lag order selection criteria. The lowest value for each criterion is its chosen VAR lag length.

Table 5. Optimal lag length

\begin{tabular}{llll}
\hline Lag & AIC & SC & HQ \\
\hline 0 & 13.66069 & 13.78067 & 13.70876 \\
1 & 8.922068 & 9.521928 & 9.16239 \\
2 & 7.598476 & 8.678224 & 8.031056 \\
3 & 7.96566 & 9.525297 & 8.590498 \\
4 & $6.133551^{*}$ & $8.173076^{*}$ & $6.950647^{*}$ \\
5 & 6.310924 & 8.830337 & 7.320278 \\
6 & 6.224939 & 9.22424 & 7.42655 \\
7 & 6.574075 & 10.05326 & 7.967945 \\
\hline
\end{tabular}

* indicates lag order selected by the criterion; AIC: Akaike information criterion; SC: Schwarz information criterion; HQ: Hannan-Quinn information criterion.

Table 6 presents the estimated VAR model. From the estimated VAR, variance decomposition and impulse response functions are generated. The variables entered the model according to their order of integration. DDMC 
and DDTOR shows that market capitalization and turnover ratio respectively were differenced twice i.e. they were integrated of order 2. GDP and investment were integrated of order 0 .

Table 6. Estimated VAR model

\begin{tabular}{|c|c|c|c|c|}
\hline & DDMC & DDTOR & GDP & INV \\
\hline \multirow[t]{3}{*}{$\operatorname{DDMC}(-1)$} & -0.049451 & 0.005827 & -0.0135 & -0.011361 \\
\hline & $(0.11963)$ & $(0.02189)$ & $(0.02679)$ & (0.01589) \\
\hline & {$[-0.41338]$} & {$[0.26620]$} & {$[-0.50401]$} & {$[-0.71496]$} \\
\hline \multirow[t]{3}{*}{$\operatorname{DDMC}(-2)$} & -0.056006 & 0.005917 & -0.016468 & -0.012067 \\
\hline & $(0.11975)$ & $(0.02191)$ & $(0.02682)$ & $(0.01591)$ \\
\hline & {$[-0.46767]$} & {$[0.27001]$} & {$[-0.61413]$} & {$[-0.75853]$} \\
\hline \multirow[t]{3}{*}{$\operatorname{DDMC}(-3)$} & -0.014682 & -0.001626 & 0.007653 & -0.008994 \\
\hline & $(0.10969)$ & $(0.02007)$ & $(0.02456)$ & $(0.01457)$ \\
\hline & {$[-0.13385]$} & {$[-0.08101]$} & {$[0.31161]$} & {$[-0.61730]$} \\
\hline \multirow[t]{3}{*}{$\operatorname{DDMC}(-4)$} & -0.401745 & 0.081814 & 0.025462 & 0.078791 \\
\hline & $(0.11727)$ & $(0.02146)$ & $(0.02626)$ & $(0.01558)$ \\
\hline & {$[-3.42571]$} & [ 3.81274$]$ & [ 0.96963$]$ & [ 5.05778] \\
\hline \multirow[t]{3}{*}{ DDTOR(-1) } & 0.078756 & -0.019268 & 0.025379 & 0.019231 \\
\hline & $(0.41431)$ & $(0.07581)$ & $(0.09277)$ & $(0.05504)$ \\
\hline & [ 0.19009$]$ & {$[-0.25416]$} & {$[0.27356]$} & [ 0.34943$]$ \\
\hline \multirow[t]{3}{*}{ DDTOR(-2) } & 0.098344 & -0.018001 & 0.034542 & 0.020507 \\
\hline & $(0.41341)$ & $(0.07564)$ & $(0.09257)$ & $(0.05492)$ \\
\hline & [ 0.23789$]$ & {$[-0.23797]$} & [ 0.37314$]$ & [ 0.37343$]$ \\
\hline \multirow[t]{3}{*}{ DDTOR(-3) } & -0.006664 & 0.000933 & -0.017091 & 0.007504 \\
\hline & $(0.39423)$ & $(0.07213)$ & $(0.08827)$ & $(0.05237)$ \\
\hline & {$[-0.01690]$} & [0.01293] & {$[-0.19361]$} & [ 0.14330$]$ \\
\hline \multirow[t]{3}{*}{ DDTOR(-4) } & -1.100649 & -0.901449 & 0.015170 & -0.089785 \\
\hline & $(0.39441)$ & $(0.07217)$ & $(0.08831)$ & $(0.05239)$ \\
\hline & {$[-2.79066]$} & {$[-12.4913]$} & {$[0.17177]$} & {$[-1.71375]$} \\
\hline \multirow[t]{3}{*}{$\operatorname{GDP}(-1)$} & -0.55243 & 0.001167 & 1.639729 & 0.014326 \\
\hline & $(0.58470)$ & $(0.10698)$ & $(0.13092)$ & $(0.07767)$ \\
\hline & {$[-0.94481]$} & [0.01091] & [ 12.5242] & [ 0.18446$]$ \\
\hline \multirow[t]{3}{*}{ GDP(-2) } & 0.495995 & -0.016058 & -0.673298 & -0.009189 \\
\hline & $(1.15464)$ & $(0.21127)$ & $(0.25854)$ & $(0.15338)$ \\
\hline & [ 0.42957$]$ & {$[-0.07601]$} & {$[-2.60418]$} & {$[-0.05991]$} \\
\hline \multirow[t]{3}{*}{ GDP(-3) } & -0.495392 & 0.078641 & -0.257352 & -0.050771 \\
\hline & $(1.15920)$ & $(0.21210)$ & $(0.25957)$ & $(0.15398)$ \\
\hline & {$[-0.42736]$} & {$[0.37077]$} & {$[-0.99147]$} & {$[-0.32971]$} \\
\hline \multirow[t]{3}{*}{ GDP(-4) } & 0.436746 & -0.091757 & 0.221342 & 0.055694 \\
\hline & $(0.59343)$ & $(0.10858)$ & $(0.13288)$ & $(0.07883)$ \\
\hline & {$[0.73596]$} & {$[-0.84504]$} & [ 1.66572$]$ & [ 0.70651$]$ \\
\hline \multirow[t]{3}{*}{$\operatorname{INV}(-1)$} & -0.46275 & 0.070491 & 0.046689 & 1.785488 \\
\hline & $(0.82669)$ & $(0.15126)$ & $(0.18511)$ & $(0.10981)$ \\
\hline & {$[-0.55977]$} & {$[0.46602]$} & [0.25223] & [ 16.2593] \\
\hline \multirow[t]{3}{*}{$\operatorname{INV}(-2)$} & 0.467779 & -0.04994 & -0.037867 & -0.797516 \\
\hline & (1.63499) & $(0.29916)$ & $(0.36610)$ & $(0.21718)$ \\
\hline & {$[0.28611]$} & {$[-0.16693]$} & {$[-0.10343]$} & {$[-3.67206]$} \\
\hline \multirow[t]{3}{*}{$\operatorname{INV}(-3)$} & -0.0161 & -0.034619 & 0.196836 & -0.09802 \\
\hline & $(1.62722)$ & $(0.29774)$ & $(0.36436)$ & $(0.21615)$ \\
\hline & {$[-0.00989]$} & {$[-0.11627]$} & [ 0.54022$]$ & {$[-0.45347]$} \\
\hline \multirow[t]{3}{*}{ INV(-4) } & -0.018186 & 0.054926 & -0.198905 & 0.078341 \\
\hline & $(0.81033)$ & $(0.14827)$ & $(0.18145)$ & $(0.10764)$ \\
\hline & {$[-0.02244]$} & [ 0.37045$]$ & [-1.09622] & [ 0.72781$]$ \\
\hline \multirow[t]{2}{*}{$\mathrm{C}$} & 0.614553 & -0.724044 & -0.06686 & 0.583330 \\
\hline & $(2.79785)$ & $(0.51193)$ & $(0.62649)$ & $(0.37166)$ \\
\hline
\end{tabular}




\begin{tabular}{lllll}
\hline & {$[0.21965]$} & {$[-1.41433]$} & {$[-0.10672]$} & {$[1.56955]$} \\
R-squared & 0.368234 & 0.712207 & 0.964049 & 0.983410 \\
Adj. R-squared & 0.212723 & 0.641366 & 0.955199 & 0.979326 \\
Sum sq. resids & 224.0005 & 7.499425 & 11.23122 & 3.952576 \\
S.E. equation & 1.856384 & 0.339670 & 0.415678 & 0.246595 \\
F-statistic & 2.367890 & 10.05357 & 108.9370 & 240.8078 \\
Log likelihood & -157.555 & -18.28535 & -34.84406 & 7.973457 \\
Akaike AIC & 4.257440 & 0.860618 & 1.264489 & 0.220160 \\
Schwarz SC & 4.756394 & 1.359572 & 1.763443 & 0.719114 \\
Mean dependent & 0.023449 & 0.003578 & 0.448710 & 17.95020 \\
S.D. dependent & 2.092204 & 0.567194 & 1.963869 & 1.715019 \\
\hline
\end{tabular}

Note. Determinant resid covariance 0.002363; Determinant resid covariance 0.000933; Log likelihood -179.3517; Akaike information criterion 6.032969; Schwarz criterion 8.028785;

\subsubsection{Granger Causality Tests}

The results of granger causality are presented in Table 7 .

Table 7. Granger causality tests using lag 4

\begin{tabular}{lccc}
\hline Null Hypothesis: & Observations & F-Statistic & Probability \\
\hline DDTOR does not Granger Cause DDMC & 82 & 1.93205 & 0.1142 \\
DDMC does not Granger Cause DDTOR & & 4.10231 & 0.0047 \\
GDP does not Granger Cause DDMC & 82 & 1.69327 & 0.1608 \\
DDMC does not Granger Cause GDP & & 0.31659 & 0.866 \\
INV does not Granger Cause DDMC & 82 & 0.80536 & 0.5257 \\
DDMC does not Granger Cause INV & & 6.38187 & 0.0002 \\
GDP does not Granger Cause DDTOR & 82 & 0.68656 & 0.6036 \\
DDTOR does not Granger Cause GDP & & 0.07866 & 0.9886 \\
INV does not Granger Cause DDTOR & 82 & 0.03199 & 0.998 \\
DDTOR does not Granger Cause INV & & 0.00984 & 0.9998 \\
INV does not Granger Cause GDP & 84 & 0.95358 & 0.4381 \\
GDP does not Granger Cause INV & & 0.06412 & 0.9923 \\
\hline
\end{tabular}

The results show that there is one-way causality that runs from stock market liberalization (MC) to economic growth (GDP). Stock market liberalization (MC) was also found to granger cause stock market performance (TOR). Therefore, the results indicate that liberalization has a positive effect to both economic growth and stock market performance. Liberalization increases market capitalization which depicts better and higher investment opportunities.

\subsubsection{Variance Decomposition}

Variance decomposition functions trace changes in each of the variables. The variables were ordered as follows; DDMC, DDTOR, GDP and lastly INV.

Table 8. Variance decomposition of DDMC

\begin{tabular}{llllll}
\hline Period & S.E. & DDMC & DDTOR & GDP & INV \\
\hline 1 & 1.856384 & 100 & 0 & 0 & 0 \\
2 & 1.883975 & 97.89703 & 0.550401 & 1.257324 & 0.295248 \\
3 & 1.898816 & 96.82764 & 0.855067 & 1.8548 & 0.462491 \\
4 & 1.926521 & 94.30142 & 1.103297 & 4.040369 & 0.554914 \\
5 & 2.148726 & 93.10691 & 2.575814 & 3.73396 & 0.583316 \\
6 & 2.149759 & 93.02892 & 2.576335 & 3.736309 & 0.658434 \\
7 & 2.153401 & 92.7495 & 2.56792 & 3.884484 & 0.7981 \\
8 & 2.159559 & 92.22979 & 2.553417 & 4.329448 & 0.887348 \\
9 & 2.224509 & 88.32026 & 6.392987 & 4.421285 & 0.865467 \\
10 & 2.226414 & 88.16932 & 6.398029 & 4.565771 & 0.866879 \\
\hline
\end{tabular}


Table 9. Variance decomposition of DDTOR

\begin{tabular}{llllll}
\hline Period & S.E. & DDMC & DDTOR & GDP & INV \\
\hline 1 & 0.33967 & 12.13382 & 87.86618 & 0 & 0 \\
2 & 0.340452 & 12.16075 & 87.62793 & 0.00152 & 0.209797 \\
3 & 0.34108 & 12.14301 & 87.40582 & 0.024547 & 0.426617 \\
4 & 0.341862 & 12.08936 & 87.06847 & 0.359652 & 0.482515 \\
5 & 0.452435 & 7.767144 & 91.64728 & 0.205967 & 0.379607 \\
6 & 0.454569 & 8.021239 & 91.00996 & 0.581868 & 0.386935 \\
7 & 0.456052 & 8.153447 & 90.52902 & 0.931257 & 0.386279 \\
8 & 0.46085 & 8.013806 & 88.72099 & 2.835929 & 0.429275 \\
9 & 0.531174 & 10.35148 & 86.75054 & 2.57469 & 0.323289 \\
10 & 0.53258 & 10.5252 & 86.48734 & 2.582993 & 0.404466 \\
\hline
\end{tabular}

Table 10. Variance Decomposition of GDP

\begin{tabular}{llllll}
\hline Period & S.E. & DDMC & DDTOR & GDP & INV \\
\hline 1 & 0.415678 & 11.96173 & 8.042761 & 79.99551 & 0 \\
2 & 0.792089 & 10.62032 & 7.982217 & 81.38046 & 0.017003 \\
3 & 1.14111 & 9.204857 & 7.853899 & 82.86945 & 0.071796 \\
4 & 1.4027 & 8.469763 & 8.413992 & 82.58778 & 0.528466 \\
5 & 1.587887 & 8.608591 & 9.092318 & 80.57836 & 1.720727 \\
6 & 1.715299 & 9.035734 & 9.823716 & 77.37021 & 3.770342 \\
7 & 1.80545 & 9.581586 & 10.45087 & 73.6869 & 6.280647 \\
8 & 1.870284 & 10.18302 & 10.91339 & 70.25693 & 8.646659 \\
9 & 1.915835 & 10.69125 & 11.35275 & 67.56045 & 10.39555 \\
10 & 1.945766 & 11.16658 & 11.71688 & 65.7281 & 11.38844 \\
\hline
\end{tabular}

Table 11. Variance decomposition of INV

\begin{tabular}{llllll}
\hline Period & S.E. & DDMC & DDTOR & GDP & INV \\
\hline 1 & 0.246595 & 0.386249 & 18.87123 & 0.264322 & 80.4782 \\
2 & 0.502615 & 0.137519 & 18.36019 & 0.373144 & 81.12914 \\
3 & 0.772274 & 0.073055 & 17.85131 & 0.537438 & 81.53819 \\
4 & 1.026097 & 0.231251 & 17.27878 & 0.560053 & 81.92992 \\
5 & 1.260439 & 0.426767 & 17.74546 & 0.551895 & 81.27587 \\
6 & 1.466009 & 1.443347 & 18.15678 & 0.482521 & 79.91735 \\
7 & 1.640478 & 3.173081 & 18.37174 & 0.409778 & 78.0454 \\
8 & 1.782193 & 5.211419 & 18.34445 & 0.347572 & 76.09656 \\
9 & 1.882675 & 6.24488 & 18.39171 & 0.341348 & 75.02206 \\
10 & 1.951886 & 6.719893 & 18.51232 & 0.377123 & 74.39067 \\
\hline
\end{tabular}

Variance Decomposition of DDMC (market capitalization). An average of $93.7 \%$ of the deviations in stock market capitalization in all the periods is attributable to its own shocks. GDP has the biggest contribution of the deviation in market capitalization with an average of $3.2 \%$. Investment contributes the lowest of the deviation in market capitalization in all the periods.

Variance Decomposition of DDTOR indicates the variance decomposition of turnover ratio. From the table, it can be seen that turnover ratio is not wholly exogenous. Much of the deviation in turnover ratio is attributable to market capitalization (MC) with $12.1 \%$ in first period and an average of $10.1 \%$ in all periods. Investment and GDP contribute an average of $0.3 \%$ and $1 \%$ respectively of the deviation in turnover ratio indicating that the relationship between TOR with GDP and investment is weak.

Variance Decomposition for GDP indicates the variance decomposition of GDP per capita growth rate. GDP is highly exogenous in the first period with $79.99 \%$ of the deviation in the variable attributable to its own shocks but the impact declines over time up to $65.7 \%$ by the tenth period demonstrating the importance of other variables that explain economic growth. The variables measuring liberalization and stock market performance, namely; market capitalization and stock turnover ratio, contributes an average of $10 \%$ and $9.6 \%$ respectively to deviations in GDP 
per capita growth rate. This shows that stock market development plays a role to economic growth.

Variance Decomposition for INV (Investment). Investment is a highly exogenous variable with an average of $79 \%$ of deviation in the variable being a result of its own shocks. Turnover ratio has the most impact with an average of $18.2 \%$ in all the periods. This shows that turnover ratio is a major determinant of investment in Kenya.

\subsubsection{Impulse Response Functions}

Figure 3 presents the graphs for impulse response functions.
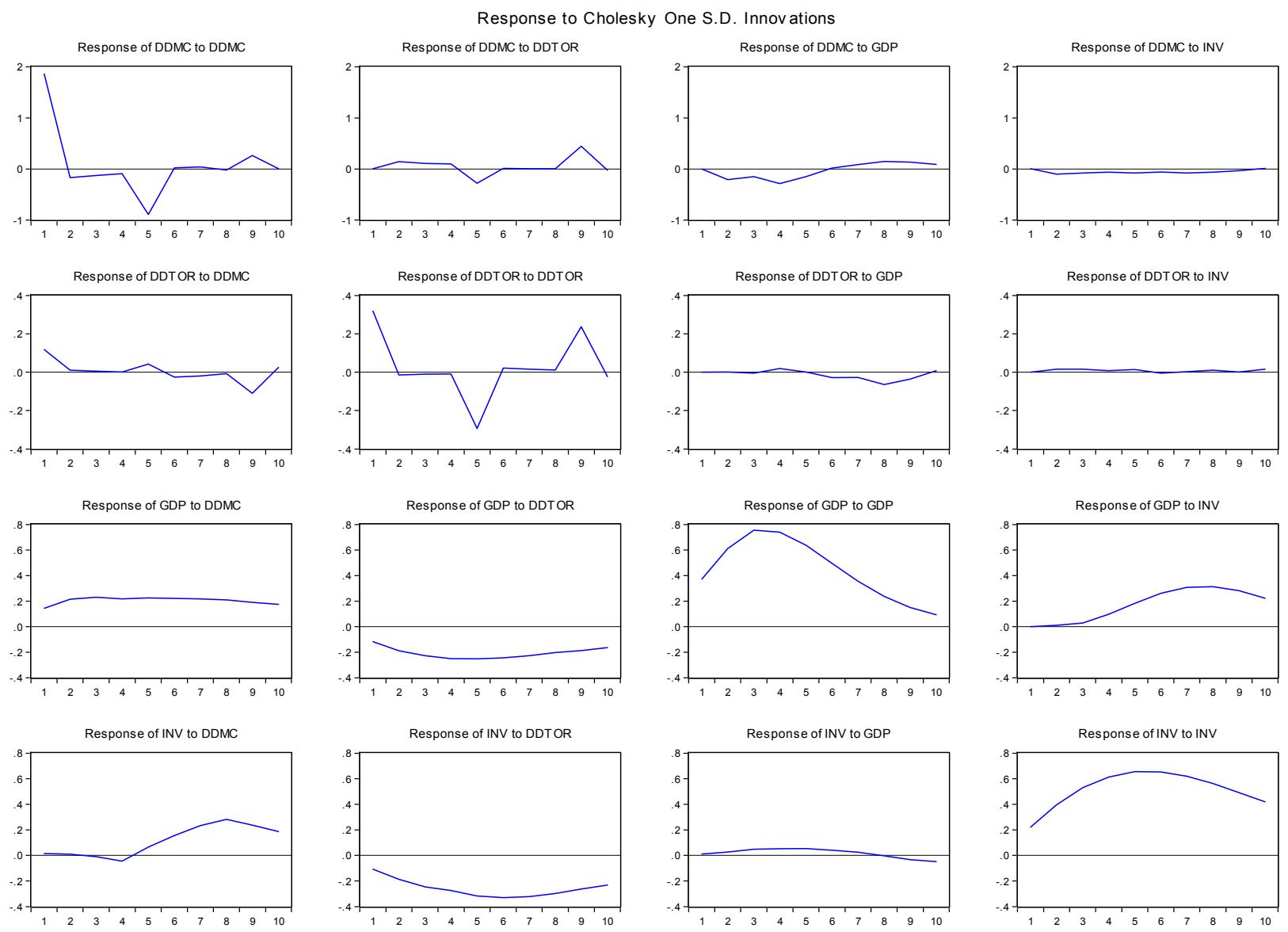

Figure 3. Impulse response functions

Impulse response functions show how each endogenous variable responds over time to innovations or shocks to each of the endogenous variables in the model and eventually how it affects the original variable itself. In this study, the response of stock market capitalization (DDMC) to turnover ratio (DDTOR), GDP per capita growth rate (GDP) and investment (INV) was insignificant. The response of turnover ratio (DDTOR) is also insignificant to the other variables. The response of GDP per capita growth rate (GDP) to turnover ratio (DDTOR) was negative for all the periods. The response of GDP to itself, stock market size (DDMC) and investment (INV) was positive for all the periods. The response of investment to itself was positive for all the periods. The response of investment to GDP is positive from period one to seven. The response of investment to turnover and stock market capitalization was insignificant.

\section{Summary, Conclusions and Policy Implications}

\subsection{Summary}

The study presumed to test whether stock market liberalization had an impact on economic growth and stock market performance. Stock market liberalization had a significant positive impact on stock market capitalization and liquidity of NSE. The study also assessed the causality between the variables. The results of the granger causality tests disclosed a one-way causality running from market capitalization to both GDP per capita and turnover ratio. 
The results of the variance decomposition indicated that market capitalization (MC) and turnover ratio (TOR) are significant variables in explaining both investment and GDP per capita growth rate. Market capitalization also explains most of the deviations in turnover ratio.

\subsection{Conclusions and Policy Implications}

Variance decomposition and Granger Causality tests display a direct positive impact of market capitalization to both GDP per capita growth rate and stock market performance. The incremental effect of stock market liberalization, as measured by stock market capitalization, had a positive effect on economic growth. The impact also came through investment and turnover. That is, market capitalization positively affecting investment and stock market liquidity and consequently investment and stock market liquidity, influencing real GDP per capita. Stock market capitalization attracts investment which has a substantial positive impact on GDP per capita growth rate.

The results propose that stock market Liberalization has a significant positive impact to both economic growth and stock market performance. It is, therefore, crucial to encourage policies that can significantly influence market capitalization and turnover ratio with an expected considerable increase in GDP per capita. It is of much significance that the government prioritizes the development and efficiency of the stock market. Subsequent policies on liberalization to further open up the NSE to foreign participation should be encouraged. Despite the role of foreign capital in the domestic economy, consideration should also be given to improving local investment and ensuring macroeconomic stability as these will improve market confidence by reducing uncertainty and drive stock market growth.

\section{Acknowledgements}

We praise the almighty God for this far He has seen us through. We have put a lot of effort in this Research Paper. However, it would not have been possible without the kind support and help of many individuals. We extend our sincere gratitude to all of them. We are very grateful to Professor Almadi Obere for his assistance and immense contributions in this study. We would also like to acknowledge the contributions of Dr. Susan Okeri, Dr. Paul Gachanja, Dr. Stephen Gitahi and Dr. Diana Ngui-Muchai. We highly appreciate the support and contributions from the Kenyatta University School of Economics teaching and non-teaching members of staff. Mr. Antony D. Bojana deserves appreciation for editing the final work.

\section{References}

Akingunola, R. O., Olusegun, A., Oluwaseyi, B., \& Olusoji, S. (2013). The effect of the financial liberalisation on economic growth. International Journal of Academic Research in Economics and Management Sciences, $1(2), 123-155$.

Diamond, D. W., \& Verrecchia, R. E. (1982). Optimal managerial contracts and equilibrium security prices. Journal of Finance, 37, 275-287. http://dx.doi.org/10.2307/2327326

Fuchs-Schundeln, N., \& Funke, N. (2001). Stock market liberalizations: Financial and macroeconomic implications. IMF Working Paper.

Henry, P. B. (2000). Stock market liberalization, economic reform, and emerging market equity prices. Journal of Finance, 55, 529-564. http://dx.doi.org/10.1111/0022-1082.00219

Henry, P., \& Chari, A. (2002). Capital account liberalization: Allocative efficiency or animal spirits? Stanford Institute for Economic and Policy Research. Stanford University, Stanford, CA.

Ibrahim, M. H. (2011). Stock market development and macroeconomic performance in Thailand. Journal of Engineering Economics, 22(3), 230-240.

Krugman, P. (1993). International finance and economic development. In A. Giovannini (Ed.), Finance and Development: Issues and Experience. (pp. 11-24). Cambridge, United Kingdom: Cambridge University Press. http://dx.doi.org/10.1017/CBO9780511983290.003

Levine, R. (1997). Financial development and economic growth: Views and agenda. Journal of Economic Literature, 35, 688-726.

Levine, R. (2000). International financial liberalization and economic growth. Review of International Economics, 9(4), 688-702. http://dx.doi.org/10.1111/1467-9396.00307

Levine, R., \& Zervos, S. (1998). Stock markets, banks, and economic growth. American Economic Review, 88, $537-558$.

McKinnon, R. (1973). Money and capital in economic development. Washington, DC: Brookings Institution. 
Ngugi, R. (2003a). Development of the Nairobi stock exchange: A historical perspective. Discussion Paper, No.27. Nairobi: Kenya Institute for Public Policy Research and Analysis.

Ngugi, R. W. (2003b). What defines liquidity of the stock market? The case of the Nairobi Stock Exchange. Discussion Paper, No.29. Nairobi: Kenya Institute for Public Policy Research and Analysis.

NSE. Annual Reports (various issues).

NSE. (1997). Rules and regulation manual. Nairobi: NSE.

Nyang oro, O. (2012). Foreign portfolio flows and stock market performance in Kenya: Case of Nairobi Securities Exchange. Unpublished PhD Thesis, University of Nairobi.

Perron, P. (1989). The great crash, the oil price shock, and the unit root hypothesis. Econometrica, 57, 1361-1401. http://dx.doi.org/10.2307/1913712

Republic of Kenya. (1969). Development Plan 1969/70. Nairobi: Government Printer.

Republic of Kenya. (1974). Development Plan 1974/78. Nairobi: Government Printer.

Sellin, P. (1996). Inviting excess volatility? Opening up a small stock market to international investors. Scandinavian Journal of Economics, 98, 603-612. http://dx.doi.org/10.2307/3440886

Shaw, E. S. (1973). Financial deepening in economic development. New York: Oxford University Press.

Tswamuno, D., Pardee, S., \& Wunnava, P. (2007). Financial liberalization and economic growth: Lessons from the South African experience. International Journal of Applied Economics, 4(2), 75-89.

Zivengwa, T., Mashika, J., Bokosi, F., \& Makova, T. (2011). Stock market development and economic growth in Zimbabwe. International Journal of Economics and Finance, 3(5), 140-150. Retrieved September 11, 2013, from http://data.worldbank.org th

\section{Appendix A}

Table A1. Raw data

\begin{tabular}{ccccc}
\hline Year & $\begin{array}{c}\text { GDP per capita growth } \\
\text { (annual \%) }\end{array}$ & $\begin{array}{c}\text { Gross fixed capital } \\
\text { formation (\% of GDP) }\end{array}$ & $\begin{array}{c}\text { Market capitalization of listed } \\
\text { companies (\% of GDP) }\end{array}$ & $\begin{array}{c}\text { Stocks traded, turnover } \\
\text { ratio (\%) }\end{array}$ \\
\hline 1990 & 0.727110224 & 20.64819763 & 5.284426275 & 2.100840336 \\
1991 & -1.870589794 & 19.03009714 & 5.55726698 & 2.428256071 \\
1992 & -3.968770791 & 16.58137009 & 7.759661783 & 2.201834862 \\
1993 & -2.762326572 & 16.93761611 & 18.42905643 & 1.649970536 \\
1994 & -0.432663066 & 18.87307148 & 43.08808039 & 2.995169082 \\
1995 & 1.423012801 & 21.38558662 & 20.84825608 & 2.617801047 \\
1996 & 1.308570394 & 16.00905817 & 15.32476023 & 3.59056806 \\
1997 & -2.154414336 & 15.38790076 & 13.90692864 & 5.776566757 \\
1998 & 0.652169016 & 15.67521329 & 14.36072205 & 4.106029106 \\
1999 & -0.300534859 & 15.59143148 & 10.92881398 & 4.316444927 \\
2000 & -1.993521692 & 16.70880651 & 10.09881652 & 3.526128972 \\
2001 & 1.062195447 & 18.15155736 & 8.084095712 & 3.410362255 \\
2002 & -2.116593629 & 17.23687985 & 10.82368779 & 2.940712613 \\
2003 & 0.186536722 & 15.83820913 & 28.03320389 & 7.456509941 \\
2004 & 2.299490344 & 16.25922348 & 24.17454021 & 8.542627628 \\
2005 & 3.091881113 & 18.69911176 & 34.06994149 & 9.825829006 \\
2006 & 3.519506154 & 19.08038312 & 50.55977256 & 14.63244911 \\
2007 & 4.173919161 & 19.36664752 & 49.14901729 & 10.64122501 \\
2008 & -1.14644589 & 19.43557648 & 35.83254664 & 11.83070729 \\
2009 & 0.02285788 & 19.64994271 & 35.15010408 & 4.58892663 \\
2010 & 2.998183793 & 20.30509846 & 44.86687141 & 8.598364668 \\
2011 & 1.601073799 & 19.98299696 & 29.7192731 & 7.119665887 \\
\hline
\end{tabular}

Source: KNBS, NSE and World Bank Databank. 


\section{Copyrights}

Copyright for this article is retained by the author(s), with first publication rights granted to the journal.

This is an open-access article distributed under the terms and conditions of the Creative Commons Attribution license (http://creativecommons.org/licenses/by/3.0/). 